\title{
PROPHYLACTIC CENTRAL NECK DISSECTION IN WELL-DIFFERENTIATED THYROID CANCER
}

\author{
Krešimir Gršić ${ }^{1}$, Boris Bumber ${ }^{1}$, Renata Curić Radivojević ${ }^{2}$ and Dinko Leović ${ }^{1,3,4}$ \\ ${ }^{1}$ Department of Otorhinolaryngology and head and neck surgery, Zagreb University Hospital Centre, Zagreb, Croatia; \\ ${ }^{2}$ Department of Anaesthesiology, Resuscitation and Intensive Care, Zagreb University Hospital Centre, Zagreb, Croatia; \\ ${ }^{3}$ Department of Otorhinolaryngology and Maxillofacial Surgery, Faculty of Medicine, \\ J. J. Strossmayer University of Osijek, Osijek, Croatia; \\ ${ }^{4}$ Department of Dental Medicine, Faculty of Dental Medicine and Health, \\ J. J. Strossmayer University of Osijek, Osijek, Croatia
}

\begin{abstract}
SUMMARY - Well-differentiated cancers, both papillary and follicular, account for $90 \%$ of all diagnosed thyroid cancers. They have an indolent disease course with a 20 -year disease-specific survival over $90 \%$. According to current guidelines, the therapy of choice for well-differentiated thyroid carcinoma is total thyroidectomy or lobectomy. The indication for prophylactic central neck dissection is still a controversial issue and the subject of unfinished and ongoing debate. There is no indication for prophylactic central neck dissection in follicular thyroid carcinomas, which primarily metastasize hematogenously. In small solitary papillary thyroid carcinomas (T1 and T2), prophylactic central neck dissection is not indicated as it does not bring benefits in terms of improved patient survival and at the same time significantly increases the risk of temporary and permanent postoperative complications. Prophylactic central neck dissection is indicated in advanced papillary thyroid cancers (T3 and T4) and all other high-risk well-differentiated thyroid cancer, as well as in the presence of metastatic lymph nodes in the lateral neck.
\end{abstract}

Key words: differentiated thyroid cancer, papillary thyroid cancer, follicular thyroid cancer, prophylactic central neck dissection, surveillance.

\section{Introduction}

According to 2018 statistical reports, thyroid cancer is the $11^{\text {th }}$ most common human cancer, with approximately 570,000 new cases per year ${ }^{1}$. Compared to statistics from ten years ago, there has been a worldwide increase in the incidence of over $100 \%^{2}$. This increase is probably not only in relation to the increased exposure of the population to known risk factors for the development of thyroid cancer but rather also due to the easy and widespread availability of diagnostic technologies, especially ultrasound ${ }^{3}$.

Corresponding author: Krešimir Gršiç, $M D, P h D$, Department of otorhinolaryngology and head and neck surgery, Zagreb University Hospital Centre, Kišpatićeva 12, 10000 Zagreb, Croatia

E-mail: kresimir.grsic@gmail.com
The peak incidence of thyroid cancer is at between 45 and 55 years of age $e^{4}$, with an overall incidence ratio of $4: 1$ in favor of women ${ }^{2}$. Overall, the five-year survival rate for thyroid cancer is excellent, at over $95 \%$, making it one of the best-treatable cancers. The mortality rate is only 0.5 deaths per 100,000 and has not changed significantly over the last 40 years 5 .

Well-differentiated cancers, both papillary and follicular, account for $90 \%$ of all diagnosed thyroid cancers. They have an indolent disease course, with a 20-year disease-specific survival of over $90 \%{ }^{6,7}$.

According to current guidelines, the therapy of choice in most patients who have cytologically verified, well-differentiated thyroid cancer (papillary or follicular) is total thyroidectomy ${ }^{8,9}$. With that approach, surgery eliminates any possibility of residual multifocal disease and allows the use of radioactive 
iodine for diagnostic and therapeutic purposes ${ }^{10}$. Serum thyroglobulin remains useful in follow-up of the disease and can be valuable for early detection of tumor recurrence. In solitary thyroid carcinomas up to 1 $\mathrm{cm}$ in diameter, it is enough to only perform a lobectomy of the affected thyroid lobe. In such cases, the contralateral lobe of the thyroid gland must have a regular echographic appearance, the cancer must not have extrathyroidal spread, and there should be no positive regional lymph nodes ${ }^{11,12}$. Such an approach for low-risk cancers is a favorable treatment for many patients today, with no adverse effect on overall survival ${ }^{13}$. Dissection of the central (levels VI and VII) and lateral regions of the neck (levels II to V) is indicated if there is cytologically verified existence of metastatic lymph nodes ${ }^{12}$. The performance of prophylactic central neck dissection is still a controversial issue and the subject of ongoing debate.

\section{Clinical anatomy and extent of comprehensive central neck dissection}

Central neck compartment is composed of level VI and the upper part of level VII (Figure 1). Level VI is cranially bounded by the hyoid bone, caudally bounded by the upper margin of the sternum, and laterally with both common carotid arteries. The superficial layer of deep cervical fascia represents the anterior border (posterior margin of the sternothyroid muscle), while a deep layer of the deep cervical fascia (prevertebral fascia) forms the posterior border. Level VI extends caudally to level VII, where the origin of the right brachiocephalic artery forms the lower edge. The nodes of the central neck area are divided into four groups: prelaryngeal (Delphian), pretracheal, left paratracheal, and right paratracheal lymph nodes (Figure 2). Prelaryngeal and pretracheal lymph nodes and lymph nodes of at least of one paratracheal region left or right - are always removed when performing central neck dissection. If both paratracheal regions are included, central neck dissection is considered to be bilateral ${ }^{14}$.

Therapeutic central neck dissection ( $\mathrm{rCND})$ is performed in all patients with clinically positive metastatic lymph nodes $(\mathrm{cN}+)$. Metastases are usually detected by clinical preoperative cytological examination or intraoperative frozen section biopsy. Prophylactic central neck dissection ( $\mathrm{pCND}$ ) removes all nodes in

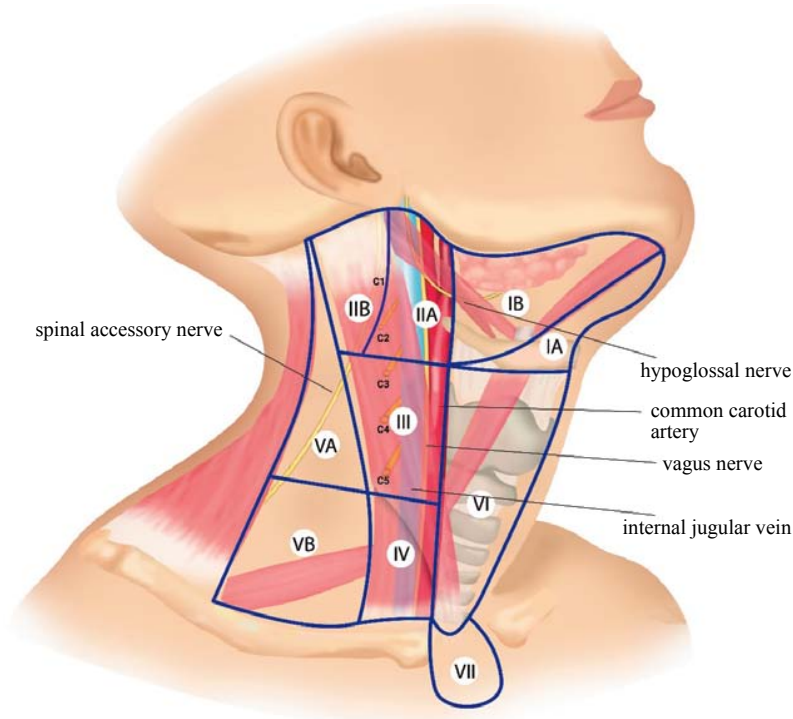

Figure 1. Lymph nodes in the neck are grouped into levels $I-V$. The central neck compartment is composed of level VI and the upper part of level VII.

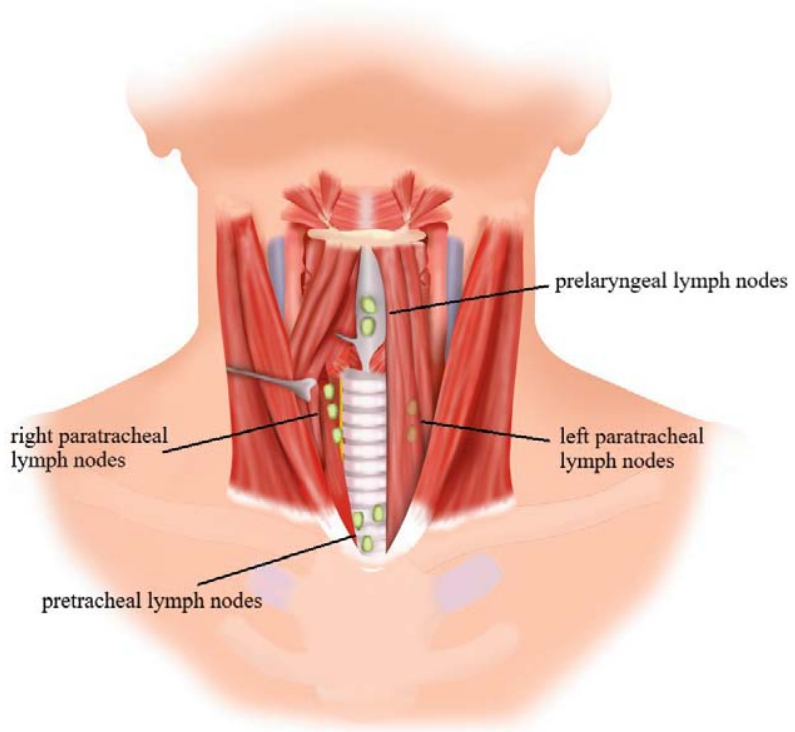

Figure 2. The nodes of the central neck area are divided into four groups: prelaryngeal, pretracheal, left paratracheal, and right paratracheal lymph nodes.

level VI and VII, although preoperative diagnostics may find no suspected lymph nodes (cN0). The extraction of the affected metastatic lymph nodes alone, i.e. keeping all others intact (berry picking), should be avoided since the possibility of metastatic recurrence in the neck after such surgery is approximately $\times 10$ higher than after complete compartment dissection ${ }^{15}$. 


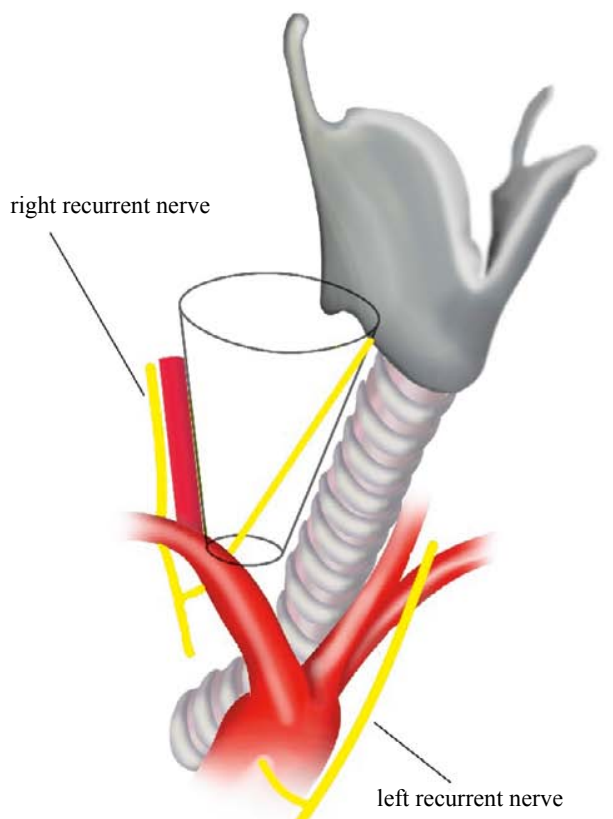

A

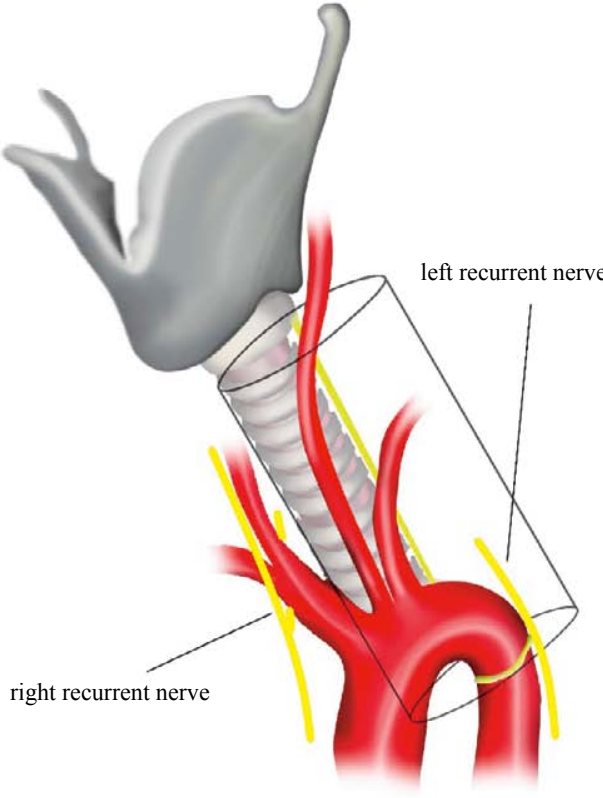

B

Figure 3. Anatomy of right and left recurrent nerves; A: right view; B: left view.

Technically, the most challenging part of central neck dissection is resection of paratracheal nodes due to necessity of preserving of all crucial structures in this region, such as the recurrent laryngeal nerve, parathyroid glands, and their vascular supply.

The clinical and anatomical features of the right and left paratracheal regions are significantly different (Figure 3). They are determined by the relationship between the recurrent laryngeal nerve and the subclavian artery on the right and the aortic arch on the left side. In the right paratracheal space, the recurrent nerve has an oblique direction from caudal to cranial, passing from lateral to medial. Depending on the relationship of the right subclavian artery to the trachea, and compared with the contralateral nerve, the right recurrent laryngeal nerve runs more ventrally through the paratracheal space, dividing the lymph nodes of this compartment into the anterior and posterior groups ${ }^{16}$. During dissection, special attention should be afforded to the posterior region, which often contains a large number of positive nodes, and is, therefore, the site of recurrence after incomplete dissections ${ }^{17}$. The left recurrent laryngeal nerve has a much simpler course. Its position is constantly dorsal and follows a groove between the trachea and esophagus in a parallel manner.
Accordingly, all lymph nodes in the left paratracheal region are in front of the recurrent laryngeal nerve ${ }^{16}$.

Good knowledge of the clinical anatomy and possible variations of the recurrent laryngeal nerve, along with fine surgical technique, is essential for its preservation and reduction of postoperative complications ${ }^{18}$. Based on cadaveric studies and intraoperative observations, more than one nerve branch has been found in 39 to $73 \%$ of patients ${ }^{19,20}$. In $89 \%$ of the cases, nerve branching occurs superior to the intersection of the recurrent laryngeal nerve and inferior thyroid artery. The damage of the most anterior branch of the recurrent laryngeal nerve, which almost exclusively carries motor fibers, leads to laryngeal musculature paresis ${ }^{21}$. The posterior branch is mainly sensory and carries motor fibers in only $8 \%$ of patients ${ }^{22}$. Injury to these will not have substantial consequences, but patients may have significant dysphagic difficulties. According to numerous authors, the pattern of extralaryngeal branching of the recurrent laryngeal nerve directly correlates with the incidence of postoperative paraly$\operatorname{sis}^{23,24}$.

While performing a paratracheal dissection, it is a surgical challenge to preserve the parathyroid glands and their vascularization. This is especially difficult for 
the inferior parathyroid gland, which in almost $90 \%$ of cases receives vascularization from the inferior thyroid artery, which passes beneath the area that should be dissected from all suspected lymph nodes. The upper parathyroid gland is somewhat easier to preserve during paratracheal neck dissection, especially in situations where it receives circulation exclusively from the superior thyroid artery. However, this anatomical variation is present in only $15 \%$ of patients ${ }^{25}$. If the parathyroid gland does not appear viable at the end of the surgery, it is advisable to perform an intraoperative frozen section biopsy to verify the tissue of the parathyroid gland. Then the parathyroid gland tissue needs to be shredded into small pieces and implanted into the ipsilateral sternocleidomastoid muscle.

\section{Preoperative evaluation of central neck}

Proper preoperative diagnostics are a prerequisite for a successful surgical plan and execution. For welldifferentiated thyroid carcinomas, it is necessary to evaluate all lymph nodes of the lateral and central neck region, as well as perform an additional examination of the central neck region intraoperatively. The basis of preoperative diagnostics is a high-resolution ultrasound scan and fine-needle aspiration (FNA) of all suspected nodes and their cytological evaluation ${ }^{26}$. The determination of thyroglobulin in aspirates of the suspicious nodes significantly increases the sensitivity of the entire process. The sensitivity and specificity in detecting lateral side metastases are several times higher than in the central region of the neck; sensitivity is $93.8 \%$ in the lateral neck compared with $30 \%$ in the central neck ${ }^{27}$. This significant difference is due to the complex anatomy of the central region of the neck. The lymph nodes of the central region are smaller in diameter, located in a groove between the thyroid, trachea, and esophagus. The air in the trachea creating artefacts represents a particular problem which makes ultrasound even more challenging. The interpretation of the ultrasound findings is highly dependent on the experience of the physician performing the examination. The presence of lymphocytic thyroiditis, which is almost regularly accompanied by inflammatory lymphadenopathy, may further complicate the interpretation of the central neck lymph nodes status ${ }^{28}$.

If there is a suspicion of extrathyroidal cancer spread with infiltration of the larynx, esophagus, trachea, and the main blood vessel in the neck, or if there is a possibility of the existence of mediastinal and retropharyngeal lymph nodes, a CT of the head and neck and thorax should be used. The use of iodine contrast when performing CT facilitates in displaying vital structures but delays the possible administration of radioactive iodine postoperatively. MR of the head and neck may be an alternative to CT; however, in the central neck region, it is far less informal compared with CT.

\section{Indication for elective central neck dissection}

It is rational to perform therapeutic central neck dissection ( $\mathrm{rCND}$ ) in patients with well-differentiated thyroid cancer in whom central neck metastases are preoperatively confirmed. The presence of positive lymph nodes and previously performed ipsilateral rCND is not an indication for contralateral pCND but requires careful additional intraoperative evaluation of the opposite paratracheal region. The prophylactic dissection of the central neck (pCND) in welldifferentiated cancers is still the subject of debate.

Proponents of pCND believe that elective central neck dissection results precise information about the stage of the disease. That information is essential in the planning of the intensity of postoperative radioiodine ablation. When performing $\mathrm{pCND}$, a possible second surgery for residual metastatic lymph nodes can be avoided. Until now, no randomized controlled trials have been conducted to provide a precise answer to the rationale for performing such surgery.

Follicular carcinomas metastasize primary hematogenously and only occasionally lymphogenously to regional lymph nodes of the neck ${ }^{29}$. Positive neck lymph nodes are found in less than $5 \%$ of patients. The most common locations for distant metastases are the lungs and brain ${ }^{30}$, found in between 6 to $20 \%$ of patients ${ }^{31,32}$. There is generally no indication for pCND in follicular cancers, except in those with clinically verified central neck metastases.

Papillary thyroid carcinomas are characterized by metastases through the lymphatic pathways, predominantly into regional lymph nodes. They most often metastasize to the lymph nodes in level VI (paratracheal) ${ }^{33}$ and later into the lateral part of the neck, mostly in level III and IV, and extremely rarely in level $\mathrm{I}^{34}$. Skip metastases to the lateral neck, in the absence of central neck metastases, are found in a total of $20 \%$ 
of cases ${ }^{35}$. They are associated primarily with cancers of the upper third of the thyroid gland and mainly metastasize to level II and III of the neck ${ }^{36-38} .83 \%$ of the patients who have positive lateral neck nodes also have microscopic metastases in the ipsilateral central region that have not been verified by any preoperative diagnostic procedure ${ }^{39}$. In these patients, there is an indication for ipsilateral $\mathrm{pCND}$ regardless of the negative clinical status of the central lymph nodes.

At the time of diagnosis of papillary thyroid carcinoma, $5-10 \%$ of patients will have clinically evident palpatory regional metastatic disease. This percentage can reach up to $30 \%$ of patients with the introduction of modern diagnostic devices such a high-resolution ultrasound with fine-needle aspiration biopsy, CT, or $\mathrm{MR}^{40-43}$. That kind of metastatic disease is defined as macroscopic disease.

Standard histopathological techniques (hematoxylin and eosin stain) typically reveal positive lymph nodes in 30 to $50 \%$ of patients undergoing an elective central and lateral neck dissection for papillary thyroid cancer ${ }^{12,44}$. After an additional immunohistochemical evaluation (i.e. cytokeratin stain) on the same surgical specimen, microscopic metastases were detected in up to $90 \%$ of patients ${ }^{33,45,46}$. This supports the theory that most patients with papillary thyroid cancer at the time of diagnosis have disseminated microscopic disease, which in most cases does not become clinically evident. It is assumed that most papillary thyroid cancers have an indolent clinical course or that levothyroxine suppression and/or radioactive iodine ablation could control the micro-metastatic nodal disease.

Previous studies have suggested that $\mathrm{pCND}$ has a positive effect on patient survival, reducing the probability of regional recurrence ${ }^{47,48}$. Nodal recurrences of the neck are characterized by macroscopic metastases with extracapsular spread, by higher lymph node density (positive/negative nodes) in neck dissection, and by the presence of more than five metastatic nodes in the dissection specimen ${ }^{49}$. Metastatic recurrences are not expected only when microscopic metastases are verified after central neck dissection ${ }^{50}$. Despite an incidence of central micrometastases between 38 and 80\%, the probability of local nodal recurrence is below $3.8 \%$, whether or not central neck dissection is performed ${ }^{29}$. Most recent studies confirm that $\mathrm{pCND}$ prevents the occurrence of regional nodal recurrences with statistical significance, but does not provide any clear benefit in long-term patient survival $1^{51-53}$.
Contrary to previous studies, Lundgren et al. (in a sample of 5,123 patients) and Zaydfudim et al. (in a sample of 33,088 patients) analyzed the metastases of patients in the central and lateral neck regions and found that presence of regional metastases correlated with decreased survival. Risk factors were age of more than 45 years in papillary cancers, male sex, metastases larger than $3 \mathrm{~cm}$ with extracapsular spread, and the pathohistological finding of widely invasive follicular cancer ${ }^{29,54,55}$.

Even if preoperative diagnostics of the central region of the neck have not verified metastatic nodes, this does not preclude the surgeon from sending suspicious nodes based on intraoperative clinical finding to intraoperative frozen-section histological analysis. Depending on the findings of the frozen-section biopsy, a conversion toward rCND can be done. Some authors affirm that the sensitivity and specificity of intraoperative frozen-section biopsy are up to $100 \%{ }^{56}$. However, even an experienced surgeon recognizes only $26 \%$ of the actual metastases based on the intraoperative appearance of the lymph node ${ }^{57}$.

According to current scientific knowledge, there is no indication for performing an ipsilateral $\mathrm{pCND}$ in smaller solitary (T1 and T2) thyroid cancers. The predisposing factors for the development of regionally metastatic disease are thyroid carcinomas of larger diameter (T3 and T4), multicenter carcinomas, carcinoma of the younger population, an aggressive subtype of carcinomas (tall cell, diffuse sclerotic, and insular) and the presence of BRAF mutations in the tumor genome ${ }^{58-62}$. In such cancers, the performance of ipsilateral pCND is indicated. However, most of the data about thyroid cancer malignant potential are available postoperatively, after an accurate histopathological analysis of the tumor. That kind of information cannot be used in an anterograde fashion in the planning of the extent of surgery and eventually performing pCND.

\section{Morbidity in elective central neck dissection}

Most authors agree that there is no significantly difference in overall survival between those with clinically negative necks in whom the elective central neck dissection is performed and those cured by comprehensive central dissection because of a clinically positive central neck ${ }^{51-53,63}$. In such circumstances, other 
issues become important, i.e. potential intraoperative and postoperative morbidity. The question is whether the benefits of surgery exceed the potential damage which neck dissection potentially carries.

Based on seventeen studies involving 1,929 $\mathrm{pa}^{-}$ tients, numerous complications are possible after central neck dissection: transient hypocalcemia in 3.6 to $60.0 \%$ of cases, permanent hypocalcemia in 0.0 to $14.4 \%$ of patients, temporary paresis of one vocal cord in 0.0 to $25.0 \%$ of cases, and permanent paralysis of the vocal cords in 0.0 to $11.5 \%$ of patients ${ }^{64}$.

Most authors have demonstrated that the percentage of complications - paresis and paralysis of the vocal cords and mainly temporary and permanent hypocalcemia - increases when central neck dissection is performed after total thyroidectomy ${ }^{65-68}$. Furthermore, a study on 103 patients revealed that bilateral central dissection carries more complications than a unilateral one, especially considering temporary and permanent hypoparathyroidism ${ }^{69}$. However, a study on $1,132 \mathrm{pa}^{-}$ tients contradicted this claim, finding no statistically significant increase in the number of post-operative adverse events, especially when an experienced surgeon performed surgery ${ }^{70}$. Zhu et al. reached a similar conclusion after analyzing nine independent studies with a total of 2,298 cases ${ }^{71}$. The same conclusion was reached by Palestini et al. in their study with a total of 305 patients $^{65}$.

An experienced surgeon is defined as one who performs over 100 thyroid surgeries each year and works in an institution where at least 150 new patients are operated on annually ${ }^{72}$. Gourin et al. showed a significant relationship between surgeon volume and surgical morbidity. They also demonstrated a favorable trend of increased volume share by high-volume surgeons and hospitals in the last 20 years. However, despite that, most thyroid surgeries are still not performed by highvolume providers ${ }^{73}$. Only prospective randomized studies in highly specialized thyroid surgery centers could give us an answer on the clinical benefit of elective neck dissections in well-differentiated thyroid carcinomas.

\section{Conclusion}

Comprehensive central neck dissection must be performed in well-differentiated thyroid cancers with positive central lymph nodes. According to current guidelines, in follicular thyroid carcinomas, which primarily metastasize hematogenously, there is no indication for prophylactic central neck dissection. In small solitary papillary carcinomas (T1 and T2 tumor), prophylactic central neck dissection is not indicated, as it does not bring benefits in terms of improved patient survival, while at the same time significantly increases the risk of temporary and permanent postoperative complications like paresis and paralysis of the recurrent laryngeal nerve and hypoparathyroidism. Prophylactic central neck dissection is indicated in large papillary thyroid cancers (T3 and T4 tumor), or small ones (T1 and T2 tumor) with high-risk factors for tumor recurrence and nodal dissemination (extrathyroidal spread or presence of BRAF mutation). Metastatic lymph nodes in the lateral neck, with a regular preoperative status of the lymph nodes of the central region of the neck, are also an indication for prophylactic central neck dissection.

\section{Conflicts of interest}

The authors have no funding or conflicts of interest to disclose.

\section{References}

1. Bray F, Ferlay J, Soerjomataram I, Siegel RL, Torre LA, Jemal A. Global cancer statistics 2018: GLOBOCAN estimates of incidence and mortality worldwide for 36 cancers in 185 countries. CA Cancer J Clin. 2018;68(6):394-424. doi:10.3322/ caac. 21492

2. La Vecchia C, Malvezzi M, Bosetti C, et al. Thyroid cancer mortality and incidence: a global overview. Int J Cancer. 2015;136(9):2187-2195. doi:10.1002/ijc.29251

3. Vaccarella S, Franceschi S, Bray F, Wild CP, Plummer M, Dal Maso L. Worldwide thyroid-cancer epidemic? The increasing impact of overdiagnosis. N Engl J Med. 2016;375:614-617.

4. Sentieri Working Group. Sentieri: mortality, cancer incidence and hospital discharges. Epidemiol Prev. 2014;38(2 Suppl 1): 5-7.

5. Davies L, Welch HG. Current thyroid cancer trends in the United States. JAMA Otolaryngol Head Neck Surg. 2014; 140(4):317-322. doi:10.1001/jamaoto.2014.1

6. Chereau N, Trésallet C, Noullet S, et al. Prognosis of papillary thyroid carcinoma in elderly patients after thyroid resection: A retrospective cohort analysis. Medicine (Baltimore). 2016;95 (47):e5450.

7. Kusić Z, Prgomet D. Karcinom štitne i doštitne žljezde. In: Prgomet D. Tumori glave i vrata. Zagreb: Medicinska naklada. 2019.p. 262-73. Croatian 
8. Paschke R, Lincke T, Müller SP, Kreissl MC, Dralle H, Fassnacht M. The Treatment of Well-Differentiated Thyroid Carcinoma. Dtsch Arztebl Int. 2015;112(26):452-458. doi: 10.3238/arztebl.2015.0452

9. Prgomet D, Bilić M, Kovac L, Hutinec Z, Topić I. Lokalno invazivni papilarni karcinom stitnjace nasa iskustva [Locally invasive papillary thyroid cancer--our experience]. Lijec Vjesn. 2012;134(9-10):266-270.

10. Hundahl SACady BCunningham MP et al. US and German Thyroid Cancer Study Group, Initial results from a prospective cohort study of 5583 cases of thyroid carcinoma treated in the United States during 1996: an American College of Surgeons Commission on Cancer Patient Care Evaluation study. Cancer 2000;89 (1) 202- 217

11. Nixon IJ, Ganly I, Patel SG, et al. Thyroid lobectomy for treatment of well differentiated intrathyroid malignancy. Surgery. 2012;151(4):571-579. doi:10.1016/j.surg.2011.08.016

12. Haugen BR, Alexander EK, Bible KC, et al. 2015 American Thyroid Association Management Guidelines for Adult Patients with Thyroid Nodules and Differentiated Thyroid Cancer: The American Thyroid Association Guidelines Task Force on Thyroid Nodules and Differentiated Thyroid Cancer. Thyroid. 2016;26(1):1-133. doi:10.1089/thy.2015.0020

13. Vargas-Pinto S, Romero Arenas MA. Lobectomy Compared to Total Thyroidectomy for Low-Risk Papillary Thyroid Cancer: A Systematic Review. J Surg Res. 2019;242:244-251. doi: 10.1016/j.jss.2019.04.036

14. American Thyroid Association Surgery Working Group; American Association of Endocrine Surgeons,; American Academy of Otolaryngology-Head and Neck Surgery; Consensus statement on the terminology and classification of central neck dissection for thyroid cancer. Thyroid. 2009;19 (11):1153-1158. doi:10.1089/thy.2009.0159

15. Musacchio MJ, Kim AW, Vijungco JD, Prinz RA. Greater local recurrence occurs with «berry picking» than neck dissection in thyroid cancer. Am Surg. 2003;69(3):191-197.

16. Shindo ML, Wu JC, Park EE. Surgical anatomy of the recurrent laryngeal nerve revisited. Otolaryngol Head Neck Surg. 2005;133(4):514-519. doi:10.1016/j.otohns.2005.07.010

17. Tufano RP, Bishop J, Wu G. Reoperative central compartment dissection for patients with recurrent/persistent papillary thyroid cancer: efficacy, safety, and the association of the BRAF mutation. Laryngoscope. 2012;122(7):1634-1640. doi: 10.1002 /lary.233712.

18. Prgomet D, Janjanin S, Bilić M, Prstacić R, Kovac L, Rudes M, Katić V. A prospective observational study of 363 cases operated with three different harmonic scalpels. Eur Arch Otorhinolaryngol. Eur Arch Otorhinolaryngol. 2009 Dec;266(12): 1965-70.

19. Henry BM, Vikse J, Graves MJ, et al. Extralaryngeal branching of the recurrent laryngeal nerve: a meta-analysis of 28,387 nerves. Langenbecks Arch Surg. 2016;401(7):913-923. doi: 10.1007/s00423-016-1455-7

20. Nemiroff PM, Katz AD. Extralaryngeal divisions of the recurrent laryngeal nerve. Surgical and clinical significance. Am
J Surg. 1982;144(4):466-469. doi:10.1016/0002-9610(82) 90425-1

21. Cho I, Jo MG, Choi SW, Jang JY, Wang SG, Cha W. Some posterior branches of extralaryngeal recurrent laryngeal nerves have motor fibers. Laryngoscope. 2017;127(11):2678-2685. doi:10.1002/lary.26595

22. Cetin F, Gürleyik E, Dogan S. Morphology and Functional Anatomy of the Recurrent Laryngeal Nerve with Extralaryngeal Terminal Bifurcation. Anat Res Int. 2016;2016:9503170. doi:10.1155/2016/9503170

23. Casella C, Pata G, Nascimbeni R, Mittempergher F, Salerni B. Does extralaryngeal branching have an impact on the rate of postoperative transient or permanent recurrent laryngeal nerve palsy?. World J Surg. 2009;33(2):261-265. doi: 10.1007/ s00268-008-9832-1

24. Sormaz IC, Tunca F, Şenyürek YG. Bilateral patterns and motor function of the extralaryngeal branching of the recurrent laryngeal nerve. Surg Radiol Anat. 2018;40(9):1077-1083. doi:10.1007/s00276-018-1989-1

25. Sadowski SM, Vidal Fortuny J, Triponez F. A reappraisal of vascular anatomy of the parathyroid gland based on fluorescence techniques. Gland Surg. 2017;6(Suppl 1):S30-S37. doi: 10.21037/gs.2017.07.10

26. Yeh MW, Bauer AJ, Bernet VA, et al. American Thyroid Association statement on preoperative imaging for thyroid cancer surgery. Thyroid. 2015;25(1):3-14. doi:10.1089/thy.2014.0096

27. Hwang HS, Orloff LA. Efficacy of preoperative neck ultrasound in the detection of cervical lymph node metastasis from thyroid cancer. Laryngoscope. 2011;121(3):487-491. doi: 10.1002/lary.21227

28. Yoo YH, Kim JA, Son EJ, et al. Sonographic findings predictive of central lymph node metastasis in patients with papillary thyroid carcinoma: influence of associated chronic lymphocytic thyroiditis on the diagnostic performance of sonography. J Ultrasound Med. 2013;32(12):2145-2151. doi:10.7863/ultra. 32.12.2145

29. Zaydfudim V, Feurer ID, Griffin MR, Phay JE. The impact of lymph node involvement on survival in patients with papillary and follicular thyroid carcinoma. Surgery 2008; 144:1070.

30. Parameswaran R, Shulin Hu J, Min En N, Tan WB, Yuan NK. Patterns of metastasis in follicular thyroid carcinoma and the difference between early and delayed presentation. Ann R Coll Surg Engl.2017;99(2):151-154.doi:10.1308/rcsann.2016.0300

31. Lin JD, Huang MJ, Juang JH et al. Factors related to the survival of papillary and follicular thyroid carcinoma patients with distant metastases. Thyroid 1999; 9: 1227-1235.

32. Schlumberger M, Challeton C, De Vathaire F et al. Radioactive iodine treatment and external radiotherapy for lung and bone metastases from thyroid carcinoma. J Nucl Med 1996;37: 598-605.

33. Noguchi S, Noguchi A, Murakami N. Papillary carcinoma of the thyroid. I. Developing pattern of metastasis. Cancer 1970; 26:1053. 
34. Caron NR, Tan YY, Ogilvie JB, et al. Selective modified radical neck dissection for papillary thyroid cancer-is level I, II and V dissection always necessary? World J Surg 2006; 30:833

35. Prstačić R, Bumber B, Marjanović Kavangh M, Jurlina M, Ivković I, Prgomet D. Metastasis predictors for neck sublevel $\mathrm{IIb}$ in papillary thyroid carcinoma [published online ahead of print, 2020 May 3]. Clin Otolaryngol. 2020;10.1111/coa. 13562. doi:10.1111/coa.13562

36. Hung YS, Kim JY, Bae JS, et al. Lateral lymph node metastasis in papillary thyroid carcinoma: results of therapeutic lymph node dissection. Thyroid 2009; 19:241.

37. Park JH, Lee YS, Kim BW, et al. Skip lateral neck node metastases in papillary thyroid carcinoma. World J Surg 2012; 36:743.

38. Bumber B, Marjanovic Kavanagh M, Jakovcevic A, Sincic N, Prstacic R, Prgomet D. Role of matrix metalloproteinases and their inhibitors in the development of cervical metastases in papillary thyroid cancer. Clin Otolaryngol. 2020;45(1):55-62. doi:10.1111/coa.13466

39. Khafif A, Ben-Yosef R, Abergel A, Kesler A, Landsberg R, Fliss DM. Elective paratracheal neck dissection for lateral metastases from papillary carcinoma of the thyroid: is it indicated?. Head Neck. 2008;30(3):306-310. doi:10.1002/hed.20696

40. Grubbs EG, Evans DB. Role of lymph node dissection in primary surgery for thyroid cancer. J Natl Compr Canc Netw 2007; 5:623.

41. Ito Y, Uruno T, Nakano K, et al. An observation trial without surgical treatment in patients with papillary microcarcinoma of the thyroid. Thyroid 2003; 13:381.

42. Stulak JM, Grant CS, Farley DR, et al. Value of preoperative ultrasonography in the surgical management of initial and reoperative papillary thyroid cancer. Arch Surg 2006; 141:489.

43. Kim E, Park JS, Son KR, et al. Preoperative diagnosis of cervical metastatic lymph nodes in papillary thyroid carcinoma: comparison of ultrasound, computed tomography, and combined ultrasound with computed tomography. Thyroid 2008; 18:411.

44. Boi F, Baghino G, Atzeni F, Lai ML, Faa G, Mariotti S. The diagnostic value for differentiated thyroid carcinoma metastases of thyroglobulin ( $\mathrm{Tg}$ ) measurement in washout fluid from fineneedle aspiration biopsy of neck lymph nodes is maintained in the presence of circulating anti-Tg antibodies. J Clin Endocrinol Metab. 2006;91(4):1364-1369. doi:10.1210/jc.2005-1705

45. Arturi F, Russo D, Giuffrida D, et al. Early diagnosis by genetic analysis of differentiated thyroid cancer metastases in small lymph nodes. J Clin Endocrinol Metab 1997; 82:1638.

46. Qubain SW, Nakano S, Baba M, et al. Distribution of lymph node micrometastasis in $\mathrm{pN} 0$ well-differentiated thyroid carcinoma. Surgery 2002; 131:249.

47. Tisell LE, Nilsson B, Mölne J, et al. Improved survival of patients with papillary thyroid cancer after surgical microdissection. World J Surg. 1996;20(7):854-859. doi:10.1007/s00268 9900130
48. Barczyński M, Konturek A, Stopa M, Nowak W. Prophylactic central neck dissection for papillary thyroid cancer. Br J Surg. 2013;100(3):410-418. doi:10.1002/bjs.8985

49. Schneider DF, Mazeh H, Chen H, Sippel RS. Lymph node ratio predicts recurrence in papillary thyroid cancer. Oncologist. 2013;18(2):157-162. doi:10.1634/theoncologist.2012-0240

50. Bardet S, Malville E, Rame JP, et al. Macroscopic lymph-node involvement and neck dissection predict lymph-node recurrence in papillary thyroid carcinoma. Eur J Endocrinol. 2008; 158(4):551-560. doi:10.1530/EJE-07-0603

51. Dobrinja C, Troian M, Cipolat Mis T, et al. Rationality in prophylactic central neck dissection in clinically node-negative (cN0) papillary thyroid carcinoma: Is there anything more to say? A decade experience in a single-center. Int J Surg. 2017;41 Suppl 1:S40-S47. doi:10.1016/j.ijsu.2017.01.113

52. Zhao W, You L, Hou X, et al. The Effect of Prophylactic Central Neck Dissection on Locoregional Recurrence in Papillary Thyroid Cancer After Total Thyroidectomy: A Systematic Review and Meta-Analysis : pCND for the Locoregional Recurrence of Papillary Thyroid Cancer. Ann Surg Oncol. 2017;24(8):2189-2198. doi:10.1245/s10434-016-5691-4

53. Chen L, Wu YH, Lee CH, Chen HA, Loh EW, Tam KW. Prophylactic Central Neck Dissection for Papillary Thyroid Carcinoma with Clinically Uninvolved Central Neck Lymph Nodes: A Systematic Review and Meta-analysis. World J Surg. 2018;42(9):2846-2857. doi:10.1007/s00268-018-4547-4

54. Lundgren CI, Hall P, Dickman PW, Zedenius J. Clinically significant prognostic factors for differentiated thyroid carcinoma: a population-based, nested case-control study. Cancer. 2006; 106(3):524-531. doi:10.1002/cncr.21653

55. Sugitani I, Kasai N, Fujimoto Y, Yanagisawa A. A novel classification system for patients with PTC: addition of the new variables of large ( $3 \mathrm{~cm}$ or greater) nodal metastases and reclassification during the follow-up period. Surgery. 2004;135 (2):139-148. doi:10.1016/s0039-6060(03)00384-2

56. Lee DH, Yoon TM, Kim HK, Lee JK, Kang HC, Lim SC. Intraoperative Frozen Biopsy of Central Lymph Node in the Management of Papillary Thyroid Microcarcinoma. Indian J Otolaryngol Head Neck Surg. 2016;68(1):56-59. doi:10.1007/ s12070-015-0900-1

57. Scherl S, Mehra S, Clain J, et al. The effect of surgeon experience on the detection of metastatic lymph nodes in the central compartment and the pathologic features of clinically unapparent metastatic lymph nodes: what are we missing when we don't perform a prophylactic dissection of central compartment lymph nodes in papillary thyroid cancer?. Thyroid. 2014;24 (8):1282-1288. doi:10.1089/thy.2013.0600

58. Howell GM, Nikiforova MN, Carty SE, et al. BRAF V600E mutation independently predicts central compartment lymph node metastasis in patients with papillary thyroid cancer. Ann Surg Oncol 2013; 20:47.

59. Zhang L, Wei WJ, Ji QH, et al. Risk factors for neck nodal metastasis in papillary thyroid microcarcinoma: a study of 1066 patients. J Clin Endocrinol Metab 2012; 97:1250. 
60. Koo BS, Choi EC, Yoon YH, et al. Predictive factors for ipsilateral or contralateral central lymph node metastasis in unilateral papillary thyroid carcinoma. Ann Surg 2009; 249:840.

61. Roh JL, Kim JM, Park CI. Central lymph node metastasis of unilateral papillary thyroid carcinoma: patterns and factors predictive of nodal metastasis, morbidity, and recurrence. Ann Surg Oncol 2011; 18:2245.

62. Horvatic Herceg G, Herceg D, Kralik M, et al. Urokinase plasminogen activator and its inhibitor type- 1 as prognostic factors in differentiated thyroid carcinoma patients. Otolaryngol Head Neck Surg. 2013;149(4):533-540. doi:10.1177/0194599813 496374

63. Molteni G, Bonali M, Mattioli F, et al. Central compartment revision surgery for persistent or recurrent thyroid carcinoma: analysis of survival and complication rate. Eur Arch Otorhinolaryngol. 2019;276(2):551-557. doi:10.1007/s00405-0185239-2

64. Sippel RS, Chen H. Controversies in the surgical management of newly diagnosed and recurrent/residual thyroid cancer. Thyroid. 2009;19(12):1373-1380. doi:10.1089/thy.2009.1606

65. Palestini N, Borasi A, Cestino L, Freddi M, Odasso C, Robecchi A. Is central neck dissection a safe procedure in the treatment of papillary thyroid cancer? Our experience. Langenbecks Arch Surg. 2008;393(5):693-698. doi:10.1007/s00423-0080360-0

66. Díez JJ, Anda E, Sastre J, et al. Prevalence and risk factors for hypoparathyroidism following total thyroidectomy in Spain: a multicentric and nation-wide retrospective analysis [published correction appears in Endocrine. 2019 Oct 22;:]. Endocrine. 2019;66(2):405-415. doi:10.1007/s12020-019-02014-8
67. Machens A, Elwerr M, Thanh PN, Lorenz K, Schneider R, Dralle H. Impact of central node dissection on postoperative morbidity in pediatric patients with suspected or proven thyroid cancer. Surgery. 2016;160(2):484-492. doi:10.1016/j. surg.2016.03.007

68. Giordano D, Valcavi R, Thompson GB, et al. Complications of central neck dissection in patients with papillary thyroid carcinoma: results of a study on 1087 patients and review of the literature. Thyroid. 2012;22(9):911-917. doi:10.1089/ thy.2012.0011

69. Lee YS, Kim SW, Kim SW, et al. Extent of routine central lymph node dissection with small papillary thyroid carcinoma. World J Surg. 2007;31(10):1954-1959. doi:10.1007/s00268007-9171-7

70. Chisholm EJ, Kulinskaya E, Tolley NS. Systematic review and meta-analysis of the adverse effects of thyroidectomy combined with central neck dissection as compared with thyroidectomy alone. Laryngoscope. 2009;119(6):1135-1139. doi:10.1002/ lary.20236

71. Zhu W, Zhong M, Ai Z. Systematic evaluation of prophylactic neck dissection for the treatment of papillary thyroid carcinoma. Jpn J Clin Oncol. 2013;43(9):883-888. doi:10.1093/jjco/ hyt087

72. Sosa JA, Bowman HM, Tielsch JM, Powe NR, Gordon TA, Udelsman R. The importance of surgeon experience for clinical and economic outcomes from thyroidectomy. Ann Surg. 1998; 228(3):320-330. doi:10.1097/00000658-199809000-00005

73. Gourin CG, Tufano RP, Forastiere AA, Koch WM, Pawlik TM, Bristow RE. Volume-based trends in thyroid surgery. Arch Otolaryngol Head Neck Surg. 2010;136(12):1191-1198. doi:10.1001/archoto.2010.212

Sažetak

\title{
INDIKACIJE ZA PROFILAKTIČKU CENTRALNU DISEKCIJU VRATA KOD DOBRO DIFERENCIRANIH KARCINOMA ŠTITNJAČE
}

\author{
Krešimir Gršić, Boris Bumber, Renata Curić Radivojević i Dinko Leović
}

Papilarni i folikularni karcinomi čine $90 \%$ svih zloćudnih tumora štitnjače. Dobro diferencirani karcinomi štitnjače imaju indolentan tijek bolesti, s dvadeset godišnjim za bolest specifičnim preživljenjem preko $90 \%$. Totalna tireoidektomija je terapija izbora za većinu bolesnika. Kod bolesnika s karcinomima niskog rizika moguće je učiniti samo lobektomiju zahvaćenog režnja, a da se pritom ne ugrozi ukupno preživljenje bolesnika. Profilaktička disekcija središnjeg dijela vrata predmet je brojnih istraživanja zbog nejasnih kliničkih posljedica njezina izvođenja. Kod folikularnih karcinoma štitnjače koji primarno metastaziraju hematogeno, nema indikacije za profilaktičku disekciju središnjeg vrata. Kod malih solitarnih papilarnih karcinoma štitnjače (T1 i T2) profilaktička disekcija središnjeg vrata nije indicirana, jer ne donosi koristi u smislu poboljšanog preživljavanja pacijenata, a istodobno značajno povećava rizik od privremenih i trajnih postoperativnih komplikacija, poput pareza i paralize povratnog laringealnog živca i hipoparatireoidizma. Ipsilateralna profilaktička disekcija središnjeg vrata indicirana je kod uznapredovalih papilarnih karcinoma štitnjače (T3 i T4) te kod svih ostalih koje karakterizira visok rizik za povrat bolesti ili regionalnu diseminaciju. Metastatski limfni čvorovi na lateralnom vratu, s urednim predoperativnim statusom limfnih čvorova središnje regije vrata, također su indikacija za profilaktičku disekciju središnjeg vrata.

Ključne riječi: dobro diferencirani karcinomi štitnjače, papilarni karcinom štitnjače, folikularni karcinom štitnjače, profilaktička disekcija središnjeg vrata, preživljenje 